\title{
Work-life Balance Initiatives of Employees' Women in Development Banks of Nepal: Employees' Perspective
}

\section{Pradip Parajuli (PhD)*}

\begin{abstract}
Work-life balance (WLB) is almost helping employees in maintaining healthy, rewarding lifestyles that will, in turn, lead to improvements in efficiency or prosperity. The study intended to explore the level of satisfaction of the working women on their personal commitments, to evaluate the working women perception on support of senior officials and to identify employee's women perspective on balance work load. This study has been based on descriptive as well as exploratory research designs were used with sample size of 40. Data was collected from four development sector banks in Nepal through structured schedules, using convenience sampling. The study provides an insight to academicians and policy makers in bank and other organizations into the needs of today's employees and initiatives taken in public sector banks for work-life balance. Other organizations might adopt these practices for helping employees attain work-life balance and hence increase their job satisfaction and organizational productivity.
\end{abstract}

Key words: Development bank, employees' women, initiative, work-life balance \& satisfaction.

\section{Introduction}

Work-life balance is that the balance between personal life and career work. Within the $1800^{\text {s, }}$ during and following the economic revolution, industrialists and unions alike agreed that workers needed each day off. This later became a two-day 'weekend'. But in those days, 'work' was mostly manual and once workers left the positioning, they also left their work behind. They were genuinely able to rest, off from work, without having to consider it or worry about what may be occurring in their absence (https://www.skillsyouneed.com/ps).

${ }^{\star}$ Dr. Parajuli is an Associate Professor in the Department of Rural Development, Patan Multiple Campus, TU, Lalitpur, Nepal.Email:parajulisp@hotmail.com 
The phrase 'work-life balance' is quite more recent in origin. It absolutely was probably first utilized in the United Kingdom within the late 1970, and within the US within the mid-1980'. It has, however, taken on a replacement meaning with the recent technological changes that have made it possible for workers to remain connected 24 hours each day, seven days every week. Smart phones, remote working technology and therefore the like have meant that, even on holiday, people find it hard to 'switch off' and genuinely rest, and therefore the complaint is commonly that folks are expected to be 'on call' in any respect times, without being allowed to own a life outside work (https:// www.skillsyouneed. $\mathrm{com} / \mathrm{ps})$.

The dichotomy between work and leisure was invented within the mid-1800 (Burke \& Peter, 2018). Anthropologists define happiness as a state of getting as little separation as possible between your work and play. The etymology of the work life balance expression is describing the balance between an individual's work and private life (Ogbonnaya et al., 2017). Work-life balance may be a term used for the concept that you simply need time for both work and other aspects of life, whether those are family-related or personal interests. The shifting social patterns have resulted in many changes in lifestyles of individuals. They need to manage personal responsibilities yet as organizational work responsibilities. Work-life balance could be a two-way process that has consideration of the requirements of employees furthermore as those of employers (Lewis, 2000).

Work-life balance practices are designed at encouraging employers to adopt such initiatives and culture as can help their employees achieve an improved balance between the strain of employers and people of private life. The concept of work-life balance relies on the notion that work-life priorities and private life priorities shouldn't be seen as challenging elements, but as complementary aspects of life. This may realize by adopting an approach that's "conceptualized as a two-way process involving a mirrored image of the requirements of employees moreover as those of employers"(ibid).

Work-life balance is a crucial aspect of a healthy work environment. Maintaining work-life balance helps reduce stress and helps prevent burnout within the workplace. Chronic stress can even negatively impact mental state because it's linked to the next risk of depression, anxiety and insomnia. Research has also indicated that employees of organizations with work-life programmes are less likely to go away the work as compared to employees of other organizations. Since women usually favor to combine work and family, work-life balance practices help employers to retain valued female employees. In other words, work-life approach would help employers retain talented and valued employees thus saving the prices associated with recruitment, interviewing and training. 
Work-life balance issues are common in today's work setting as numerous employees feel overwhelmed by an imbalanced life that becomes clear with symptoms like depression, stress because of responsibilities, lack of energy and enthusiasm for daily activities, etc.

Many public sector and personal sector organizations in Nepal are getting tuned in to the importance of helping employees attain work-life balance and are adopting strategies to realize the identical. This study was undertaken to search out practices of work-life balance in development sector banks of Nepal. Different researchers have explained differently on what constitutes work-life balance practice.

A work-life balance practice that features organizational support for dependent care, flexible work choices, and family or personal leave (Estes \& Michael, 2005). For them these practices contain flexible work hours (e.g. flex time and compressed work week, engaging from home, job sharing), family leave programs (e.g. parental leave, adoption leave, and sympathetic leave), and on-site childcare, and financial and / or informational support with childcare and eldercare services.

Occupation opportunities, within the variety of prospects for improvement within a corporation or more generally in one's chosen field, are impacted by family assurances. The utilization of flexible working performs by employers designed to help employees to balance their work and residential and therefore the desire for a balanced lifestyle between work and family also distresses decisions to vary jobs or accept a geographical transfer. It can help to shape employees' intentions to alter a company or a complete career. after all young people's occupational choices are influenced by the way within which they prioritize their work and family roles, which they have a tendency to put a high value on both work and family instead of on one or the opposite (Smithson, 1999).

Consequently, an outsized a part of them have attended is present at their workplace for extended periods of your time, thereby reducing the time that they're available reception. The web and mobile phones have made it possible for the organizations to stay in constant touch with the workers both during the day and at midnight (Morgan, 2003). Increasing workloads have pressurized employees to demonstrate their commitment to figure in additional obvious ways (Ishaya \& Ayman, 2008). Work-life balance is an essential and demanding issue within the 21 st century.

Concerns like child rearing, the wants to balance multiple roles, etc., have consequences on health and relation (Konrad \& Mangel, 2016). The relations are slowly vanishing. Small nuclear families have come to remain, where both the spouses visit work. Additionally, there are an increasing number of single parent households because of increase in divorces 
ratio. Cultural norms and values are fast facing the changes like women participants in workforce, parents working, single-parent homes, etc., leading to strengthening of the necessity to integrate work and family life as part of everyday reality and a bitter one too.

The new global economy, with its specialize in full-time availability and long work hours, only worsens the matter generated by the lag within the organizations of paid works, as if workers were without personal interests or domestic care concerns (Roehling et al., 2001). Work-life balance practices are favorable for employers as they affect several employee attitudes. The disadvantages related to work-life imbalance are numerous and impact both employee and employers. Work-life balance efforts may well be of two types; policies designed to produce care services (information and referral services, financing of kid care or elder care, etc.) and people designed to come up with more flexible work arrangements (flexible schedules that let flexible starting and vacating times, telecommunicating, compacted workweeks, job sharing, etc.).

Several studies have found that when employees have supervisors who support workfamily balance, job satisfaction is higher and work-family conflict is lower (Bowen, 1998). Work-life balance practices don't necessarily influence levels of employee worklife conflict, but progress on organizational performance by the way of reduced overheads within the case of employees functioning from home, better-quality productivity among employees performing at their peak hours, or social exchange processes rising from perceptions of organizational backing.

\section{Objectives of the Study}

The broad objective of the study is to investigate extent to which work-life balance affects initiatives of employees' women in development banks from the employee's perspective in selected development banks of Nepal. The following are the specific objectives:

i. To examine the level of satisfaction on their personal commitments of the employees' women of selected development bank.

ii. To evaluate the employees' women perception on support of senior officials of development banks.

iii. To identify development banks employee's women perspective on their balance work load. 


\section{Research Methodology}

This study has been based on descriptive as well as exploratory research design. Study had been carried out in the employees' women of four development banks purposely in Kathmandu Metropolitan City, ward no. 32, Koteshwor, Kathmandu, Nepal. There were 83 women out of 165 staffs. Almost half of the employee's women 40 were selected purposively as a sample size. Nature of the data was qualitative as well as quantitative. Primary data were collected through interview schedule and observation as data collection techniques. Schedule has been used which is divided into two parts. First part is related to demographic and socio-economic profile of the respondents and second part contains the variables to study the perception.

\section{Respondents Profile}

The demographic characteristics include age, sex, and marital status of the respondents. Results as shown in Table 1 revealed that out of 40, the majority of the respondents 26 , $(65 \%)$ were in the age group of $20-45$. Only 5 respondents $(12.5 \%)$ were in the age group of below 19, the minority of the respondents are in the age group of above $45,9(22.5 \%)$. All the respondents were female and married.

Table 1: Socio demographic profile of the respondents

\begin{tabular}{|c|c|c|c|}
\hline \multicolumn{2}{|c|}{ Socio-demographic profile } & \multirow{2}{*}{$\begin{array}{c}\text { Number } \\
5\end{array}$} & \multirow{2}{*}{$\begin{array}{c}\text { Percent } \\
12.5 \\
\end{array}$} \\
\hline \multirow{3}{*}{ Age group } & Below 19 & & \\
\hline & 20 to 45 & 26 & 65 \\
\hline & 45 above & 9 & 22.5 \\
\hline \multirow{5}{*}{ Caste/ethnicty } & Brahmin & 12 & 30 \\
\hline & Chhetri & 10 & 25 \\
\hline & Damai/ Kami/Sarki & 4 & 10 \\
\hline & Gurung/Magar/Tamang & 6 & 15 \\
\hline & Newar & 8 & 20 \\
\hline \multirow{3}{*}{ Religion } & Hindu & 28 & 70 \\
\hline & Buddhist & 9 & 22.5 \\
\hline & Christian & 3 & 7.5 \\
\hline
\end{tabular}




\begin{tabular}{|l|l|c|c|}
\hline \multirow{4}{*}{ Education } & Up to school level & 8 & 20 \\
\cline { 2 - 4 } & Up to bachelor & 22 & 55 \\
\cline { 2 - 4 } & Above bachelor & 10 & 25 \\
\hline \multirow{4}{*}{ Designation } & Assistance & 11 & 27.5 \\
\cline { 2 - 4 } & Cashier/ Secretary/ Receptionist & 26 & 65 \\
\cline { 2 - 4 } $\begin{array}{l}\text { Economic status of } \\
\text { family }\end{array}$ & Manager/ Supervisor & 3 & 7.5 \\
\hline & Not enough & 5 & 12.5 \\
\cline { 2 - 4 } & Enough & 25 & 62.5 \\
\cline { 2 - 4 } & Surplus & 10 & 25 \\
\hline
\end{tabular}

Source: Field Survey, 2019

Along with these demographic characteristics, caste/ethnicity, religion, education, designation, and family economic status of respondents were taken as socio-economic status. The above data shows that $12(30 \%)$ respondents majority of the respondents were from Brahmin, 10 (25\%) respondents from Chhetri, 8 (20\%) respondents were Newar, $6(15 \%)$ respondents were Gurung/Magar/Tamang, and only $4(10 \%)$ respondents were Damai/Kami/Sarki. The majority of the respondents were from the Hindu religion, 28 (70\%), Buddhist religions were $9(22.5 \%)$ and only a few respondents are from the Christian religion, $3(7.5 \%)$. With the majority of respondents $22(55 \%)$ belonging to up to bachelor level. Among them $10(25 \%)$ respondents were above bachelor level and only a few $8(20 \%)$ of them were up to school level education. The majority of the respondents 26 (65\%) were in Cashier/Secretary/ Receptionist, 11 (27.5\%) were Assistance and only a few respondents $3(7.5 \%)$ were in the Manager/Supervisor designation. Among the respondent's family economic status, the majority of the respondents 25 (62.5) were middle class family, 10 (25\%) respondents were high class family and a few $5(12.5 \%)$ respondents were in the low class family.

\section{Satisfactions on Personal Commitments}

To examine the level of satisfaction on their personal commitments of the employees' women were asked their banks provides flexible time that help in managing work-life balance, satisfactions with the numbers of hours to work in a day, whether they are getting time for entertainments, and were able to spend considerable time with family considered hereunder. 
Table 2: Distribution of the respondents by satisfaction on personal commitments

\begin{tabular}{|l|l|c|c|}
\hline \multicolumn{1}{|c|}{ Variables } & \multicolumn{1}{c|}{ Classification } & Number & Percent \\
\hline \multirow{3}{*}{$\begin{array}{l}\text { Flexible time to manage } \\
\text { work-life balance }\end{array}$} & Fully & 8 & 20 \\
\cline { 2 - 4 } & Partially & 20 & 50 \\
\cline { 2 - 4 } & Not at all & 12 & 30 \\
\hline \multirow{3}{*}{$\begin{array}{l}\text { Satisfied to hours to } \\
\text { work per day }\end{array}$} & Fully & 10 & 25 \\
\cline { 2 - 4 } & Partially & 18 & 45 \\
\cline { 2 - 4 } & Not at all & 12 & 30 \\
\hline \multirow{3}{*}{$\begin{array}{l}\text { Getting time on } \\
\text { entertainments }\end{array}$} & Fully & 23 & 20 \\
\cline { 2 - 4 } & Partially & 9 & 57.5 \\
\cline { 2 - 4 } & Not at all & 10 & 22.5 \\
\hline \multirow{3}{*}{$\begin{array}{l}\text { Spending time with } \\
\text { family }\end{array}$} & Fully & 22 & 25 \\
\cline { 2 - 4 } & Partially & 8 & 55 \\
\cline { 2 - 4 } & Not at all & & 20 \\
\hline
\end{tabular}

Source: Field Survey, 2019

The data shows that half of the respondents, 20 (50\%) responded that they don't have fully flexible time to manage work-life balance. The minority of the respondents, 12 $(30 \%)$ reported that they were not able to manage work-life balance. Only a few $8(20 \%)$ respondents reported that they were fully managing work-life balance.

In order to disclose the satisfaction to hours to work per day, respondents were asked whether they have satisfied to hours to work per day or not nearly half $18(45 \%)$ respondents reported that they don't have fully satisfied to work per day. $12(30 \%)$ of the respondent reported that they were not satisfied to work per day. But only a few $10(25 \%)$ of them reported that they are fully satisfied to hours to work per day.

To explore getting time on entertainments, they were asked whether they have getting time on entertainments or not, Majority of the respondents $23(57.5 \%)$ reported that they have partially getting time on entertainments. $9(22.5 \%)$ reported that they were not getting time on entertainments, but only a few 8 (20\%) respondents reported that they were getting time on entertainments.

In order to disclose the spending time with family, respondents were asked whether they have time spending with family, the majority 22 (55\%) respondents reported that they 
have partially spending time with family. 10 (25\%) respondents reported they have time to spending with family, but only $8(20 \%)$ respondents reported that they don't have time to spend with family.

\section{Perception on Support of Senior Officials}

To evaluate the employees' women perception on support of senior officials of development banks, respondents were asked superior has concern for your personal problem, any counseling from superiors whenever required, family get-together organized by bank, giving time to fulfill social commitments, and any initiatives to help employees manage their personal lives. Their responses are shown given below.

Table 3: Distribution of the respondents by perception on support of senior officials

\begin{tabular}{|l|l|c|c|}
\hline \multicolumn{1}{|c|}{ Variables } & \multicolumn{1}{|c|}{ Classification } & Number & Percent \\
\hline \multirow{3}{*}{$\begin{array}{l}\text { Concern for personal } \\
\text { problem }\end{array}$} & Fully & 3 & 7.5 \\
\cline { 2 - 4 } & Partially & 20 & 50 \\
\cline { 2 - 4 } & Not at all & 17 & 42.5 \\
\hline \multirow{3}{*}{$\begin{array}{l}\text { Counselling whenever } \\
\text { reuired }\end{array}$} & Fully & 6 & 15 \\
\cline { 2 - 4 } & Partially & 22 & 30 \\
\cline { 2 - 4 } & Not at all & 2 & 55 \\
\hline \multirow{3}{*}{$\begin{array}{l}\text { Family get-together } \\
\text { organze }\end{array}$} & Fully & 3 & 5 \\
\cline { 2 - 4 } & Partially & 35 & 87.5 \\
\cline { 2 - 4 } & Not at all & 22 & 20 \\
\hline \multirow{3}{*}{ Fulfil social commitments } & Fully & 10 & 55 \\
\cline { 2 - 4 } & Partially & 8 & 25 \\
\cline { 2 - 4 } & Not at all & 21 & 20 \\
\hline \multirow{2}{*}{$\begin{array}{l}\text { Initiative to manage } \\
\text { personal lives }\end{array}$} & Fully & 11 & 27.5 \\
\cline { 2 - 4 } & Partially & & \\
\cline { 2 - 4 } & Not at all & 2.5 \\
\hline
\end{tabular}

Source: Field Survey, 2019

The above data shows that half of the respondents 20 (50\%) reported that they their superior has partially concern for personal problem. minority of the respondent $17(42.5 \%)$ reported that their superior were not concerning for personal problem, but only a few $3(7.5 \%)$ respondents reported that their superior were fully concerning for personal problem. 
To understand the counseling from their superiors whenever required, respondents were asked whether they were counseling from their superiors whenever needed, the majority of the respondents $22(55 \%)$ reported that they don't have experienced of counseling from their superiors whenever required. $12(30 \%)$ respondent reported that they have a partially counseling from superiors, but only a few $6(15 \%)$ respondents reported that they were fully getting counseling from their superiors whenever required.

Based on data received it can be said that the overwhelm majority of the respondents 35 $(87.5 \%)$ reported that they don't have experienced of family get-together organize by organization. $3(7.5 \%)$ respondents reported that have experience of family get-together organize by seniors but not by organization. Only 2(2.5\%) respondents reported that they have fully experienced of family get-together organize by organization.

The above data shows that the majority of the respondents $22(55 \%)$ reported that they were partially fulfilling social commitments. 10 (25\%) respondents reported that they were not able to fulfil social commitments but only a few respondents $8(20 \%)$ reported that they were fully fulfil social commitments.

To understand the experience of initiative to manage personal lives, respondents were asked whether their organization has taken good initiatives to help managing their personal lives, almost half respondent $21(52.5 \%)$ reported that they have partially getting initiative to manage personal life. $11(27.5 \%)$ reported that they don't have any initiatives to manage their personal lives, but only a few $8(20 \%)$ respondents reported that they were fully having initiative to manage personal lives.

\section{Perspective on Balance Work Load}

To identify development banks employee's women perspective on their balance work load respondents were asked feeling tired and depressed because of work, able to manage the stress arising out of work, and getting enough time for sleep and maintaining a healthy life style considered hereunder. 
Table 4: Distribution of the respondents by perspective on balance work load

\begin{tabular}{|l|l|c|c|}
\hline \multicolumn{1}{|c|}{ Variables } & \multicolumn{1}{|c|}{ Classification } & Number & Percent \\
\hline \multirow{3}{*}{$\begin{array}{l}\text { Feel tired and depressed because } \\
\text { of work }\end{array}$} & Fully & 19 & 47.5 \\
\cline { 2 - 4 } & Partially & 12 & 30 \\
\cline { 2 - 4 } & Not at all & 9 & 22.5 \\
\hline \multirow{3}{*}{$\begin{array}{l}\text { Able to manage the stress arising } \\
\text { out of work }\end{array}$} & Fully & 10 & 25 \\
\cline { 2 - 4 } & Partially & 16 & 40 \\
\cline { 2 - 4 } & Not at all & 8 & 35 \\
\hline \multirow{3}{*}{$\begin{array}{l}\text { Enough time for sleep and } \\
\text { maintaining healthy life style }\end{array}$} & Fully & 12 & 20 \\
\cline { 2 - 4 } & Partially & 20 & 30 \\
\cline { 2 - 4 } & Not at all & 50 \\
\hline
\end{tabular}

Source: Field Survey, 2019

The above data shows that over almost half of the respondents $19(47.5 \%)$ reported that they have experienced of feel tired and depressed because of work. $12(30 \%)$ respondents reported that they are partially feeling tired and depress because of work and, only a few $9(22.5 \%)$ respondents reported that they don't have experienced of feeling tired and depressed because of work.

To understand the able to manage the stress arising out of work, respondents were asked whether they were able to manage the stress arising out of work. Minority 16 (40\%) respondents reported that they were partially able to manage the stress arising out of work, $14(35 \%)$ respondents reported that they not able to manage the stress arising out of work and, only a few $10(25 \%)$ respondents reported that they were fully able to manage the stress arising out of work.

Based on data received it can be said that half of the respondents $20(50 \%)$ reported that they don't have enough time for sleep and maintaining healthy life. $12(30 \%)$ respondents reported that they ha have experienced of belittling or humiliating. Minority $12(30 \%)$ respondents reported that have partially enough time for sleep and maintain healthy life. Only a few 8 $(20 \%)$ respondents reported that they have enough time for sleep and maintain healthy life.

\section{Findings}

- Only a few $8(20 \%)$ respondents reported that they were fully managing work-life balance. 
- Respondents, $10(25 \%)$ of them reported that they are fully satisfied to hours to work per day.

- Only a few $8(20 \%)$ respondents reported that they were getting time on entertainments.

- Respondents, 10 (25\%) reported they have enough time to spending with family.

- Only a few $3(7.5 \%)$ respondents reported that their superior were fully concerning for personal problem.

- Respondents, $6(15 \%)$ reported that they were fully getting counseling from their superiors whenever required.

- Only 2(2.5\%) respondents reported that they have fully experienced of family gettogether organize by organization.

- Only a few respondents $8(20 \%)$ reported that they were fully fulfilling social commitments.

- Only a few $8(20 \%)$ respondents reported that they were fully having initiative to manage personal lives.

- Almost half of the respondents 19 (47.5\%) reported that they have experienced of feel tired and depressed because of work.

- Only a few 10 (25\%) respondents reported that they were fully able to manage the stress arising out of work.

- Only a few $8(20 \%)$ respondents reported that they have enough time for sleep and maintain healthy life.

\section{Conclusion}

The research accompanied to study work-life balance initiatives of employees' women in development banks of Nepal: employees' perspective resulted in three factors, which in their order of importance are; satisfactions on personal commitments, perception on support of senior officials and perspective on balance work load.

Satisfactions on personal commitments lead to involvement in different activities so that one can enjoy his life by adequate sleeping, fresh food, family and job thus maintaining work-life balance. The study shows that only few were fully managing work-life balance, satisfied to hours to work per day, time for entertainments and spending time with family. But the majority of employee's were not satisfied on these issues. Senior officials are the foremost motivators of the work-life balance. There positive attitude towards the employees can help to maintain work-life balance. Only a few $3(7.5 \%)$ respondents reported that their 
superior were fully concerning for personal problem. The study shows that only few were experienced getting counseling from their superiors whenever required, family get-together organizes by organization, fully fulfilling social commitments and, having initiative to manage personal lives. The majority were not fully satisfied on these issues.

Increases on the work load of the employees, which becomes causes of stress that can result in loss in efficiency or prosperity of the organization. The study shows that many of them feel tired and depressed because of work, unable to manage the stress arising out of work, and don't have enough time for sleep and maintain healthy life.

\section{References}

Bowen, G. (1998). Effect of leaders support in the work unit on the relationship between work spillover and family adaptation. Journal of Family Economy Issues, 19, 25-52.

Burke, S. A., \& Peter, N. (2018). The influence of work life balance reflections on employee satisfaction. Serbin Journal of Management, 6 (1), 85-96.

Estes, S. B., \& Michael, J. (2005). Work-family policies and gender inequality at work: A sloan work and family encyclopedia entry. http://wfnetwork.bc.edu/encyclopedia entry.php

Ishaya, N., \& Ayman, R. (2008). Predicting work-family conflict via perceived involvement and overload, Boston, M A: American Psychological Association.

Konrad, J., \& Mangel, E. (2016). Literature review of issues related to work-life balance, workplace culture and maternity/childcare issues. Crisis pregnancy agency: Summary report of the consultation for the strategy to address the issue of crisis pregnancy. https://doi.crisispregnancy.ie/pub/Rep3.pdf

Lewis, J. (2000). Employers, lone parents and the work-life balance. Sheffield: Department for Work and Pension.

Morgan, H. (2003). The challenges of a global marketplace. In M. Goldsmith, R. Gandosssy, and M. Effron (Ed.). Human resources in the $21^{\text {st }}$ century, New York: Wiley.

Ogbonnaya, N. M., Daniel, K., Connolly, K. M., \& Veldhoven, K., (2017). Empirical analysis of work life balance policies and its impact on employee's job satisfaction and performance: Descriptive statistical approach. American Journal of Theoretical and Applied Statistics, 4 (2), 33-43. 
Roehling, P. V., Roehling, M. V., \& Moen, P. (2001). The relationship between work-life policies and practices and employee loyalty: A life course perspective. Journal of Family and Economic Issues, 22 (2), 70-141.

Smithson, J. (1999). Equal choices, different futures: Young adults talk about work and family expectations. Psychology of Women Section Review, 1, 43-57. https:// www. skillsyouneed.com/ps 